\title{
Size-control growth of thermally stable Au nanoparticles encapsulated within ordered mesoporous carbon framework
}

\author{
Shuai Wang a, Jie Wang a, Xiaojuan Zhu a, Jianqiang Wang b, Osamu Terasaki c, Ying Wan a,* \\ a The Education Ministry Key Laboratory of Resource Chemistry, Shanghai Key Laboratory of Rare Earth Functional Materials, and Department of \\ Chemistry, Shanghai Normal University, Shanghai 200234, China \\ b Shanghai Synchrotron Radiation Facility (SSRF), Shanghai Institute of Applied Physics, Chinese Academy of Sciences, Shanghai 201204, China \\ c Arrhenius Laboratory, Department of Physical, Inorganic and Structural Chemistry, Stockholm University, Stockholm 10691, Sweden
}

\section{A R T I C L E I N F O}

\section{Article history:}

Received 3 March 2015

Accepted 8 May 2015

Published 5 January 2016

Keywords:

Gold nanoparticles

Size

Carbon

Mesoporous

\begin{abstract}
A B S T R A C T
Simultaneously controlling the size of Au nanoparticles and immobilizing their location to specific active sites while hindering migration and sintering at elevated temperatures is a current challenge within materials chemistry. Typical methods require the use of protecting agents to control the properties of Au nanoparticles and therefore it is difficult to decouple the influence of the protecting agent and the support material. By functionalizing the internal surface area of mesoporous carbon supports with thiol groups and implementing a simple acid extraction step, we are able to design the resulting materials with precise control over the Au nanoparticle size without the need for the presence of any protecting group, whilst simultaneously confining the nanoparticles to within the internal porous network. Monodispersed Au nanoparticles in the absence of protecting agents were encapsulated into ordered mesoporous carbon at various loading levels via a coordination-assisted self-assembly approach. The X-ray diffractograms and transmission electron microscopy micrographs show that the particles have controlled and well-defined diameters between 3 and $18 \mathrm{~nm}$ at concentrations between 1.1 and $9.0 \mathrm{wt} \%$. The Au nanoparticles are intercalated into the pore matrix to different degrees depending on the synthesis conditions and are stable after high temperature treatment at $600{ }^{\circ} \mathrm{C}$. $\mathrm{N}_{2}$ adsorption-desorption isotherms show that the Au functionalized mesoporous carbon catalysts possess high surface areas (1269-1743 $\left.\mathrm{m}^{2} / \mathrm{g}\right)$, large pore volumes $\left(0.78-1.38 \mathrm{~cm}^{3} / \mathrm{g}\right)$ and interpenetrated, uniform bimodal mesopores with the primary larger mesopore lying in the range of 3.4-5.7 nm and the smaller secondary mesopore having a diameter close to $2 \mathrm{~nm}$. X-ray absorption near extended spectroscopy analysis reveals changes to the electronic properties of the Au nanoparticles as a function of reduced particle size. The predominant factors that significantly determine the end $\mathrm{Au}$ nanoparticle size is both the thiol group concentration and subjecting the as-made materials to an additional concentrated sulfuric acid extraction step.
\end{abstract}

(C) 2016, Dalian Institute of Chemical Physics, Chinese Academy of Sciences. Published by Elsevier B.V. All rights reserved.

\section{Introduction}

$\mathrm{Au}$ catalysts have attracted significant attention since being reported as exhibiting high catalytic activity by Haruta, Hutch-

\footnotetext{
* Corresponding author. Tel: +86-21-64322516; Fax: +86-21-65322511; E-mail: ywan@shnu.edu.cn

This work was supported by the State Key Basic Research Program of China (2013CB934102), the National Natural Science Foundation of China (21322308, 21173149), the Program for Changiiang Scholars and Innovative Research Team in University (PCSIRT-IRT1269), the Research Fund for the Doctoral Program of Higher Education (20123127110004), and Shanghai Science \& Technology and Education Committee (11JC1409200, DZL123, S30406).

DOI: 10.1016/S1872-2067(15)60917-2 | http://www.sciencedirect.com/science/journal/18722067 | Chin. J. Catal., Vol. 37, No. 1, January 2016
} 
ings and co-workers [1-3]. Such Au catalysts have found applications in areas such as selective oxidation [4-6], hydrogenation [7-10], epoxidation [11,12] and coupling reactions [13, 14]. Correlation of catalytic activity to the resulting particle size and the catalyst-support interface is crucial when considering their design and therefore isolating the Au nanoparticles to a desired location and increasing dispersion is a prerequisite for improved catalysis [15-18].

Activated carbon has been recently reported as scaffolds for Au nanoparticles $[19,20]$, because of their many superior advantages to their oxide counterparts, such as stability in both acidic and basic environments and thermal stability up to 900 ${ }^{\circ} \mathrm{C}$ under inert atmospheres [21]. Additionally, activated carbon supports do not strongly interact with Au nanoparticles, which may take advantage of the particle size effect while minimizing the interface interaction effect for $\mathrm{Au}$ and oxide. Research publications related to $\mathrm{Au}$ supported on carbon lacks numbers when compared with Au supported on oxides, possibly because of the diverse origin of carbon, the redox properties and the ease in reducing $\mathrm{Au}(\mathrm{III})$ precursors resulting in, for example, the formation of large metallic aggregates. A colloidal deposition method was first developed by Rossi and co-workers to obtain 3-nm Au particles on activated carbon [22]. Protecting groups are always used [23-25]. It has been established that both the carbon support and the protecting agents can influence the overall activity of Au catalysts [21,26-29]. For example, particle size can be governed by the functionality of the protecting agent and thus alterations in both steric hindrance and the electronic properties of the $\mathrm{Au}$ nanoparticles results. Therefore, it remains a challenge to decouple the influences of the carbon supports' textural properties, the surface functionality-to include the protecting groups-which are highly related to the diffusion of liquid reactants and the properties intrinsic to the Au catalyst such as particle size and metal surface area [21]. Another problematic route leading to the rapid reduction of active sites is the occurrence of nanoparticle sintering during post-synthetic heat treatment of catalysts whereby the protective polymers are removed [30].

Compared with activated carbon possessing wide pore size distributions, ordered mesoporous carbons with well-defined mesoporous architectures and high surface areas are an example of an alternative support [31-35]. Nanocasting methods can be adopted to replicate Au-supported mesoporous carbon by using Au-containing functionalized SBA-15 silicates [36-40] as hard templates. However, the growth of nanoparticles from 2 to $7 \mathrm{~nm}$ occurs upon high-temperature treatment during the replication, which leads to low nanoparticle dispersion [33]. Additionally, the pore size from carbon that has undergone nanocasting is also difficult to tailor.

Intercalation of nanoparticles inside frameworks to improve stability is attractive [36-40]. For example, sulfur-containing silanes or silsesquioxanes are used to coordinate with Au species during triblock copolymer or surfactant self-assembly. The final products confine 2-7 nm Au nanoparticles in the walls of mesoporous (organo)silica. Very recently, our group developed a one-step coordination-assisted approach for the intercalation of monodispersed Au nanoparticles inside mesoporous carbon walls [35]. The nanocatalysts show high activity and reusability in aerobic oxidation of alcohols. The limitation is however, that the nanoparticle size and the content are fixed to $9.0 \mathrm{~nm}$ and $\sim 6.0 \mathrm{wt} \%$, respectively. A pre-carbonization of the framework by sulfuric acid can yield Au nanoparticles with a size $\sim 3.4 \mathrm{~nm}$ [41]. In this work, we demonstrate how to control both the size and density of the Au catalysts within the mesoporous carbon framework. By tuning the thiol functional group density with/without additional extraction of the template, stable $\mathrm{Au}$ nanoparticles in the absence of protecting agents, ranging from 3 to $18 \mathrm{~nm}$ in size and $0.01-0.09 \mathrm{~g} / \mathrm{g}$ in concentration, are confined by the mesoporous carbonaceous frameworks upon carbonization at $600{ }^{\circ} \mathrm{C}$. Nanoparticle aggregation is inhibited even at higher Au loadings. The reduction of the particle size results in changes to the electronic properties of the Au nanoparticles. As the resulting catalysts are stable at high temperature and are resistant to acid or base etching, the ability to tailor pore size and surface functionality retains the integrity of the nanoparticles and mesostructure. This allows for multiple tailoring of the catalyst properties for specific applications related to $\mathrm{Au}$-supported mesoporous carbon catalysts.

\section{Experimental}

\subsection{Synthesis of ordered mesoporous $\mathrm{Au} / \mathrm{C}$}

In a typical synthesis of 9-Au(6)/C, Pluronic F127 (3.2 g; $\mathrm{EO}_{106} \mathrm{PO}_{70} \mathrm{EO}_{106}, M_{w}=12600$, Acros) was dissolved in an acidic ethanol solution ( $2.0 \mathrm{~g}$ of $0.2 \mathrm{~mol} / \mathrm{L} \mathrm{HCl}, 10.0 \mathrm{~g}$ of ethanol) at 40 ${ }^{\circ} \mathrm{C}$ prior to the addition of an ethanolic $\mathrm{HAuCl}_{4}$ solution $(6.3 \mathrm{~mL}$, $48.5 \mathrm{mmol} / \mathrm{L}$ ) under stirring. Thereafter, a mixture containing TEOS (2.08 g), (3-Mercaptopropyl)trimethoxysilane (MPTMS; $1.97 \mathrm{~g}$ ) and ethanol (10.0 g) together with a solution containing preformed phenolic resins (2.0 g, prepared as described in references [34,35]) and ethanol (8.0 g) were added in sequence. After $2 \mathrm{~h}$, the mixture was poured into dishes. The dishes were placed in a hood to evaporate ethanol at $40^{\circ} \mathrm{C}$ for $5 \mathrm{~h}$, and after to thermopolymerize at $100{ }^{\circ} \mathrm{C}$ for $24 \mathrm{~h}$. The as-made films were ground into fine powders and termed: as-made 9-Au(6)/C. Removal of the block copolymer and carbonization of the as-made materials were achieved by calcination under $\mathrm{N}_{2}$ via a temperature-controlled program from room temperature to $600{ }^{\circ} \mathrm{C}$. Silica was removed from the composite by treatment with $\mathrm{NaOH}$ (1 mol/L). Specifically, the as-made 9-Au(6)/C sample was submerged for $12 \mathrm{~h}$ in a $\mathrm{NaOH}$ solution at $45{ }^{\circ} \mathrm{C}$ under stirring and repeated three times, each with a fresh alkaline solution. Finally, the mesoporous carbon-supported $\mathrm{Au}$ catalysts were washed with copious amounts of distilled water, and dried at $80{ }^{\circ} \mathrm{C}$ overnight under vacuum before activating the products by heat treatment at $150{ }^{\circ} \mathrm{C}$ for $4 \mathrm{~h}$ in air. The molar ratio for MPTMS/(MPTMS+TEOS) was tuned from 17\% to $50 \%$ and $\mathrm{Au}$ incorporated into the final support within the range of $0.01-0.1 \mathrm{~g} / \mathrm{g}$. The detailed synthesis information was listed in Table 1 . The final products were named as $x-A u(y) / C$, in which $x$ represents the $\mathrm{Au}$ nanoparticle size of the $\mathrm{Au} / \mathrm{C}$ catalysts and $y$ represents Au content supported on the carbon. An optional sulfuric acid extraction step prior to high-temperature 
Table 1

The detailed synthesis information in the sol-gel solution for ordered mesoporous $\mathrm{Au} / \mathrm{C}$.

\begin{tabular}{lccc}
\hline Sample & $\begin{array}{c}\mathrm{HAuCl}_{4} \\
(\mathrm{mmol})\end{array}$ & $\begin{array}{c}\text { MPTMS } \\
(\mathrm{mmol})\end{array}$ & $\begin{array}{c}\text { TEOS } \\
(\mathrm{mmol})\end{array}$ \\
\hline $3-\mathrm{Au}(6) / \mathrm{C}$ & 0.31 & 10 & 10 \\
9-Au(1)/C & 0.05 & 10 & 10 \\
9-Au(2)/C & 0.10 & 10 & 10 \\
$9-\mathrm{Au}(6) / \mathrm{C}$ & 0.31 & 10 & 10 \\
9-Au(9)/C & 0.49 & 10 & 10 \\
$14-\mathrm{Au}(6) / \mathrm{C}$ & 0.31 & 6.65 & 13.3 \\
$18-\mathrm{Au}(1) / \mathrm{C}$ & 0.05 & 3.30 & 16.7 \\
$18-\mathrm{Au}(6) / \mathrm{C}$ & 0.31 & 3.30 & 16.7 \\
$100-\mathrm{Au}(6) \& \mathrm{C}$ & 0.31 & 0 & 20 \\
\hline
\end{tabular}

treatment was performed on the as-made 9-Au(6)/C material. The composites were twice refluxed in $50 \mathrm{wt} \%$ sulfuric acid with mechanical stirring (typically $1.0 \mathrm{~g}$ of as-made material per $100 \mathrm{~mL}$ of $50 \mathrm{wt} \%$ sulfuric acid) at $90^{\circ} \mathrm{C}$ for $24 \mathrm{~h}$. The resultant materials were filtered, washed with distilled water and dried at $80^{\circ} \mathrm{C}$ under vacuum overnight. This solid was designed as as-made 3-Au(6)/C. The following heating procedure and silica removal step are both exactly the same as above.

\subsection{Characterization}

The X-ray diffraction (XRD) measurements were recorded on a Rigaku Dmax-3C diffractometer using $\mathrm{Cu} K_{\alpha}$ radiation (40 $\mathrm{kV}, 20 \mathrm{~mA}, \lambda=0.15408 \mathrm{~nm}$ ). The metallic Au sizes were estimated according to the Scherrer formula on the basis of the 111 peak reflection from the wide-angle XRD diffractograms. $\mathrm{N}_{2}$ adsorption-desorption isotherms were measured at $-196^{\circ} \mathrm{C}$ with a Micromeritics TriStar II 3020 analyzer. The Brunauer-Emmett-Teller (BET) method was utilized to calculate the specific surface areas ( $\left.S_{\mathrm{BET}}\right)$. By using the Barrett-JoynerHalenda (BJH) model, the pore volumes and pore size distributions were derived from the adsorption branch of the isotherms. Transmission electron microscopy (TEM) analysis was conducted on a JEOL JEM 2100 microscope operated at $200 \mathrm{kV}$. Energy dispersive X-ray spectroscopy (EDX) was performed on a Philips EDAX instrument. Fourier transform infrared (FT-IR) spectra were collected on Nicolet Fourier spectrophotometer.
Thermal gravimetric analysis (TGA) curves were monitored on a Mettler Toledo 851e apparatus. X-ray photoelectron spectroscopy (XPS) measurements were recorded on a Perkin-Elmer PHI 5000CESCA system with a base pressure of 10-9 Torr. Au content was determined by inductively coupled plasma-atomic emission spectrometry (ICP-AES, Varian VISTAMPX). The S content was measured on a Vario EL III elemental analyzer (Elementar, Germany). The temperature of the combustion tube was $1150{ }^{\circ} \mathrm{C}$ and the reduction tube at $850{ }^{\circ} \mathrm{C}$. X-ray absorptions near extended spectra (XANES) at the Au $L 3$ edge of samples were collected in fluorescence mode on the BL14W1 line of the Shanghai Synchrotron Radiation Facility (SSRF). Data were processed using the program ATHENA. All Extended X-ray Absorption Fine Structure (EXAFS) data were fitted using the program ARTEMIS.

\section{Results and discussion}

\subsection{Characterization results}

The first set of catalyst materials had a fixed Au content, while the density of the thiol groups protruding from the walls of the as-made material ranged from 1.55 to $3.06 \mathrm{mmol} / \mathrm{g}$ by tuning the addition of MPTMS from 3.30 to $10 \mathrm{mmol}$ in the synthesis batch [42]. After carbonization and silica removal, the $\mathrm{Au}$ content for this set of $\mathrm{Au} / \mathrm{C}$ catalysts is $\sim 6 \mathrm{wt} \%$, determined by ICP-AES (Table 2). TEM micrographs for 3-, 9-, 14-, 18-Au(6)/C show typical 2D hexagonal mesostructure. When the electron beam is perpendicular to the alignment of the pores, cylindrical pores are observed. With the incident beam is aligned parallel to the pores, the hexagonal ordering is clearly discernable. This is also true for the Au-free material establishing that the $\mathrm{Au}$ loading does not affect the overall long-range integrity of the mesostructure (Fig. 1). It is evident that monodispersed $\mathrm{Au}$ nanoparticles of tunable size are present on the carrier carbon supports. No observable large particles present outside the ordered mesopores clearly indicate that the thermally stable $\mathrm{Au}$ nanoparticles have been confined within the mesoporous carbonaceous matrix. In a previous report, HRSEM micrographs of the surface and cross section of the $9-\mathrm{Au}(6) / \mathrm{C}$ material, as well as the cross section after polishing were rec-

Table 2

Structural and textural properties of Au-supported mesoporous carbon catalysts.

\begin{tabular}{|c|c|c|c|c|c|c|c|}
\hline Catalyst & $\begin{array}{c}\text { Au content }^{\mathrm{a}} \\
(\mathrm{wt} \%)\end{array}$ & $a_{0}{ }^{\mathrm{b}}(\mathrm{nm})$ & $S_{\mathrm{BET}}\left(\mathrm{m}^{2} / \mathrm{g}\right)$ & $V_{\mathrm{t}}\left(\mathrm{cm}^{3} / \mathrm{g}\right)$ & $D_{\mathrm{p}}(\mathrm{nm})$ & $d_{\mathrm{Au}}{ }^{\mathrm{c}}(\mathrm{nm})$ & $d_{\mathrm{Au}}{ }^{\mathrm{d}}(\mathrm{nm})$ \\
\hline As-made 9-Au(6)/C & n.g. & 12.7 & - & - & - & - & - \\
\hline As-made $3-A u(6) / C$ & n.g. & 11.6 & 66 & 0.08 & 5.6 & - & - \\
\hline $3-\mathrm{Au}(6) / \mathrm{C}$ & 5.3 & 8.1 & 1269 & 0.79 & 3.4 & 3.4 & 3 \\
\hline $9-\mathrm{Au}(6) / \mathrm{C}$ & 5.8 & 8.0 & 1635 & 1.09 & 4.0 & 8.9 & 9 \\
\hline $9-\mathrm{Au}(1) / \mathrm{C}$ & 1.1 & 8.0 & 1634 & 1.06 & 3.8 & 8.5 & 9 \\
\hline $9-\mathrm{Au}(2) / \mathrm{C}$ & 1.8 & 8.1 & 1706 & 1.12 & 4.1 & 9.7 & 9 \\
\hline $9-\mathrm{Au}(9) / \mathrm{C}$ & 9.0 & 9.2 & 1529 & 1.01 & 4.0 & 9.9 & 9 \\
\hline $14-\mathrm{Au}(6) / \mathrm{C}$ & 6.0 & 9.0 & 1564 & 1.11 & 4.4 & 13.8 & 14 \\
\hline $18-\mathrm{Au}(1) / \mathrm{C}$ & 1.3 & 10.6 & 1349 & 1.11 & 5.6 & 18.4 & 18 \\
\hline $18-A u(6) / C$ & 5.7 & 10.4 & 1743 & 1.38 & 5.7 & 17.9 & 18 \\
\hline $100-A u(6) \& C$ & 5.7 & 11.0 & 1331 & 1.23 & 6.0 & 150 & 50 \\
\hline
\end{tabular}

a Estimated by ICP-AES. ${ }^{\mathrm{b}}$ Cell parameter of the mesostructure. ${ }^{\mathrm{c} E s t i m a t e d}$ from TEM analysis of average diameter. ${ }^{\mathrm{d}}$ Calculated from the Scherrer formula according to the (111) diffraction. n.g.-not given. 


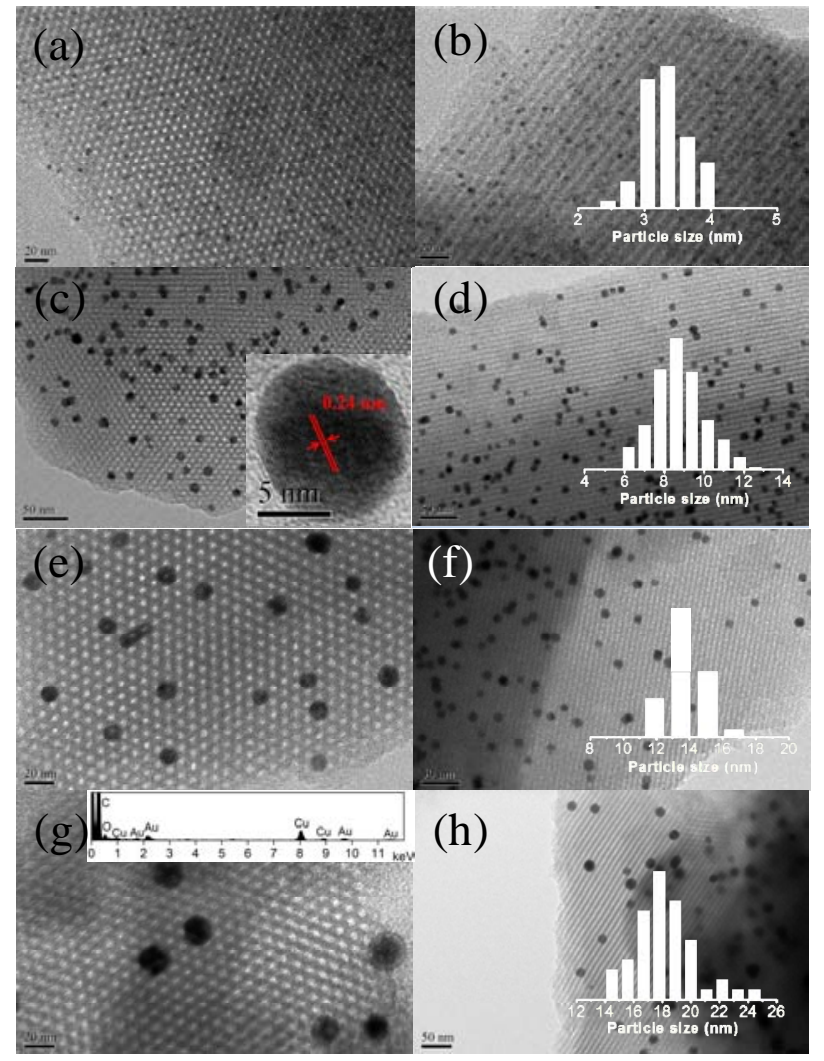

Fig. 1. TEM micrographs for Au-containing mesoporous carbon catalysts with varying particle sizes viewed along the (001) (a, c, e, g) and (110) (b, d, f, h) directions. (a, b) 3-Au(6)/C; (c, d) 9-Au(6)/C; (e, f) 14- $\mathrm{Au}(6) / \mathrm{C} ;(\mathrm{g}, \mathrm{h}) 18-\mathrm{Au}(6) / \mathrm{C}$. Inset $(\mathrm{b}, \mathrm{d}, \mathrm{f}, \mathrm{h})$ is the corresponding metal particle size distribution histogram. Inset (c) is an expanded HRTEM micrograph of a Au nanoparticle. Inset (g) displays the EDX pattern.

orded [35] and the Au nanoparticles can only be observed after cross section polishing, further indicating the intercalation of $\mathrm{Au}$ nanoparticles inside the framework rather than on the external surface of the mesostructured solids. In contrast to the $100 \mathrm{Au}(6) \& \mathrm{C}$ sample, synthesized in the absence of thiol func-

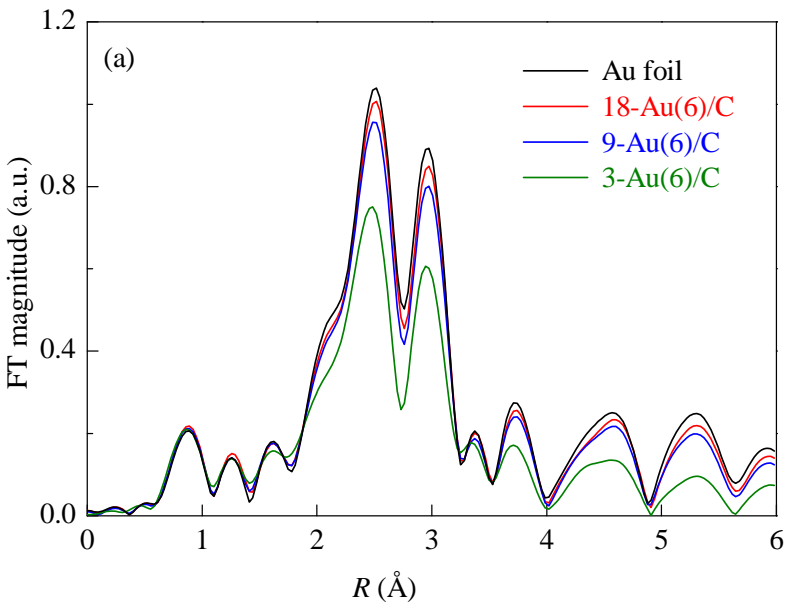

tional groups, a distinct phase separation between large $\mathrm{Au}$ nanoparticles $(150 \mathrm{~nm})$ and the ordered mesostructure domains is observed (not shown here).

The average nanoparticle size of $3.4 \mathrm{~nm}$ is observed for the 3-Au(6)/C catalyst, the nanoparticles each having a semiexposure morphology (Fig. 1(a,b)). The nanoparticles are part encapsulated with the carbon wall while the remainder protrudes out into the channels of the pore. In relation to the $9-\mathrm{Au}(6) / \mathrm{C}$ material, the nanoparticle size averages $\sim 9.0 \mathrm{~nm}$ in size. Observation reveals that the particles span the entire width of the pore channels up to the adjacent pore walls, however, the nanoparticles do not penetrate into the carbon walls (Fig. 1(c, d)). The HRTEM micrograph of a representative $\mathrm{Au}$ particle in 9-Au(6)/C shows crystalline Au particles with the characteristic $0.24 \mathrm{~nm} \mathrm{Au}\{111\}$ lattice fringe. With respect to the 14- and 18-Au(6)/C materials, the $\mathrm{Au}$ nanoparticle diameters exceed the pore width and hence penetrate the pore walls of the adjacent pore channels (Fig. 1(e-h)). Though the size of the Au nanoparticles, especially in 9-, 14-, and $18-\mathrm{Au}(6) / \mathrm{C}$, is obviously larger than that of the pores, the integrity of the carbon network was not so severely damaged by the $\mathrm{Au}$ encapsulation. EDX analysis reveals the undetected S or Si (Fig. 1(g), the other materials display similar results, not shown). This result suggests that the functional groups have been volatilized during calcinations similar to Au-containing mesoporous silicates [38-40], and the silica components have been removed by $\mathrm{NaOH}$ etching.

The Fourier transform intensities of the $k$-weighted EXAFS functions are shown in Fig. 2(a) for the Au samples with varying nanoparticle sizes, and that of $\mathrm{Au}$ foil is also included for comparison. Similar higher-shell features to the Au foil are found, indicating the existence of clustered $\mathrm{Au}$ atoms, consistent with an $f c c$-structure retained in the Au nanoparticles. The Au clusters in the supported samples have a reduction in the $\mathrm{Au}-\mathrm{Au}$ coordination number in the order of $\mathrm{Au}$ foil > 18-Au(6)/C > 9-Au(6)/C > 3-Au(6)/C (Table 3), possibly because of the decreasing particle size and therefore the enhanced surface area-to-volume ratio. The relative first nearest $\mathrm{Au}-\mathrm{Au}$ length contraction and the Debye-Waller factor changes

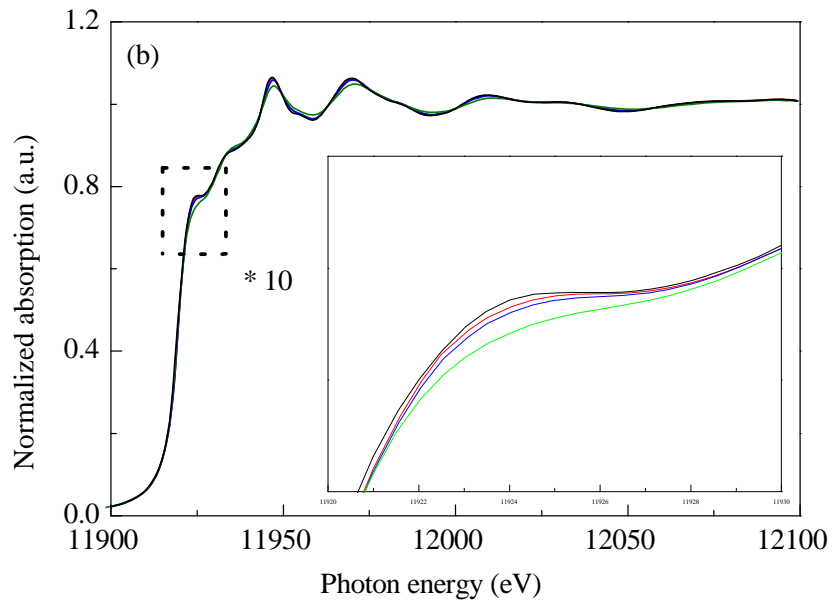

Fig. 2. Fourier transform of EXAFS (a) and Au L3 edge XANES (b) spectra for ordered mesoporous Au supported carbon catalysts with different Au sizes along with that of $\mathrm{Au}$ foil. The inset in (b) is an expanded region of the intensity changes of the white line (within the dashed box). The legend in inset (b) is exactly the same in (a). 
Table 3

Fit parameters of $\mathrm{Au} \mathrm{L} 3$ edge EXAFS spectra for $100 \mathrm{Au}(6) / \mathrm{C}, 18-\mathrm{Au}(6) / \mathrm{C}, 9-\mathrm{Au}(6) / \mathrm{C}$ and 3-Au(6)/C catalysts together with the reference $\mathrm{Au}$ foil.

\begin{tabular}{lcrccc}
\hline Sample & Shell & \multicolumn{1}{c}{$N^{\mathrm{a}}$} & $R^{\mathrm{b}}$ & $\sigma^{2 \mathrm{c}}\left(10^{-3} \AA^{2}\right)$ & \multicolumn{2}{c}{$\Delta E_{0} \mathrm{~d}(\mathrm{eV})$} \\
\hline $3-\mathrm{Au}(6) / \mathrm{C}$ & $\mathrm{Au}-\mathrm{Au}$ & $8.6 \pm 0.8$ & $2.84 \pm 0.01$ & $8.9 \pm 0.7$ & $5.9 \pm 0.6$ \\
$9-\mathrm{Au}(6) / \mathrm{C}$ & $\mathrm{Au}-\mathrm{Au}$ & $10.1 \pm 0.8$ & $2.86 \pm 0.01$ & $8.6 \pm 0.5$ & $5.9 \pm 0.5$ \\
$18-\mathrm{Au}(6) / \mathrm{C}$ & $\mathrm{Au}-\mathrm{Au}$ & $10.3 \pm 0.8$ & $2.86 \pm 0.01$ & $8.3 \pm 0.5$ & $5.9 \pm 0.4$ \\
$100-\mathrm{Au}(6) \& \mathrm{C}$ & $\mathrm{Au}-\mathrm{Au}$ & $10.4 \pm 0.8$ & $2.86 \pm 0.01$ & $8.3 \pm 0.5$ & $5.2 \pm 0.5$ \\
$\mathrm{Au}$ foil & $\mathrm{Au}-\mathrm{Au}$ & $10.6 \pm 0.8$ & $2.86 \pm 0.01$ & \\
\hline
\end{tabular}

${ }^{\mathrm{a}}$ Coordination number. ${ }^{\mathrm{b}}$ Distance between absorber and backscatterer atoms. ${ }^{\mathrm{c}}$ Debye-Waller factor. ${ }^{\mathrm{d}}$ Inner potential correction.

as a function of the inverse Au-cluster diameter. Because mesoporous carbon does not strongly interact with the support, the contracted lattice is mainly attributed to the enhanced surface energy (nanosize effect) [43].

The normalized XANES spectra of the supported $\mathrm{Au}$ at the L3 edges is shown in Fig. 2(b), which probes the unoccupied densities of $d$ states (the white line of $L 3$-edge is mainly because of the $2 p_{3 / 2} \rightarrow 5 d$ dipolar transitions while the $2 p_{3 / 2} \rightarrow 6 s$ contribution is negligibly small). Similar three peak patterns are observed for the studied Au-containing mesoporous carbons as for the bulk $\mathrm{Au}$ foil within the first $40 \mathrm{eV}$ above the edge, which are characteristic of an $f c c$ structure in the nanoparticles. The mesoporous carbon-confined $\mathrm{Au}$ nanoparticles exhibit a noticeable decrease in the white line intensity as compared with $\mathrm{Au}$ foil in the order of $3-\mathrm{Au}(6) / \mathrm{C}<9-\mathrm{Au}(6) / \mathrm{C}<$ $18-\mathrm{Au}(6) / \mathrm{C}$. The ideal electron configuration of $\mathrm{Au}$ is $5 d^{10} 6 s^{1}$; however, because of rehybridization, large clusters have an electron configuration of $5 d^{10-x} 6 s^{1+x}$, with the $d$-band density of states closer to the Fermi level and increased holes in the $d$-band [44]. The smaller particles in 3-Au(6)/C with a shorter $\mathrm{Au}-\mathrm{Au}$ distance and enhanced $d$ - $d$ interactions favor $s$ - $d$ rehybridization, narrow $d$-bands, lower $d$-orbital energy and increasing the $d$-electron count at the Au site in the nanoparticles $[41,45,46]$.

The small-angle XRD patterns for all Au-containing mesoporous carbon materials show typical diffractions belonging to the ordered mesophase (Fig. 3(a)). With the decrease in Au nanoparticle size (S concentration increasing), the cell parameter reduces from 10.4 to $8.0 \mathrm{~nm}$. By comparison, the Au-free samples after carbonization with the initial S loading increasing from 1.55 to $3.06 \mathrm{mmol} / \mathrm{g}-\mathrm{SH}$ show decreasing cell parameters from 12.4 to $11.0 \mathrm{~nm}$ [42]. These phenomena imply extended framework shrinkage by both smaller nanoparticles and the concentration of MPTMS in the as-made materials. Relatively diffused wide-angle attributed to $f c c \mathrm{Au}$ is detected, further confirming metallic Au nanoparticles. The Au sizes calculated by the Scherrer formula range from 3 to $18 \mathrm{~nm}$ (Fig. 3(b)), complementary to the TEM micrographs. The Au-containing mesoporous carbon materials display typical type-IV isotherms, revealing uniform mesopore distributions (Fig. 4, Table 2). Increased adsorption after the initial sharp capillary inflection shows the uptake of adsorbate at low relative pressures between $p / p_{0}$ of 0.01-0.3 implying the presence of an abundance of small pores in the region of $2 \mathrm{~nm}$. A bimodal pore size distribution is observed for all $\mathrm{Au} / \mathrm{C}$ catalysts. A similar phenomenon has been found in a Au-free mesoporous carbon material-formed from a carbon-silica composite-with a so-called "reinforced-concrete" pore wall, homogeneous in the carbon and silica distribution [35,47-49]. After etching away the silica component the emergence of small pores result in the distinct nitrogen adsorption at low relative pressures. Therefore, in the present $\mathrm{Au} / \mathrm{C}$ catalysts, the large mesopores are generated by the removal of triblock copolymer and the small mesopores originate from the etched silica component inside the pore walls. High surface areas of $1269-1743 \mathrm{~m}^{2} / \mathrm{g}$ and large pore volumes of $0.79-1.38 \mathrm{~cm}^{3} / \mathrm{g}$ were achieved because of a large number of voids. The primary pore size reduces as a function of decreasing Au nanoparticle size, in the same order as the
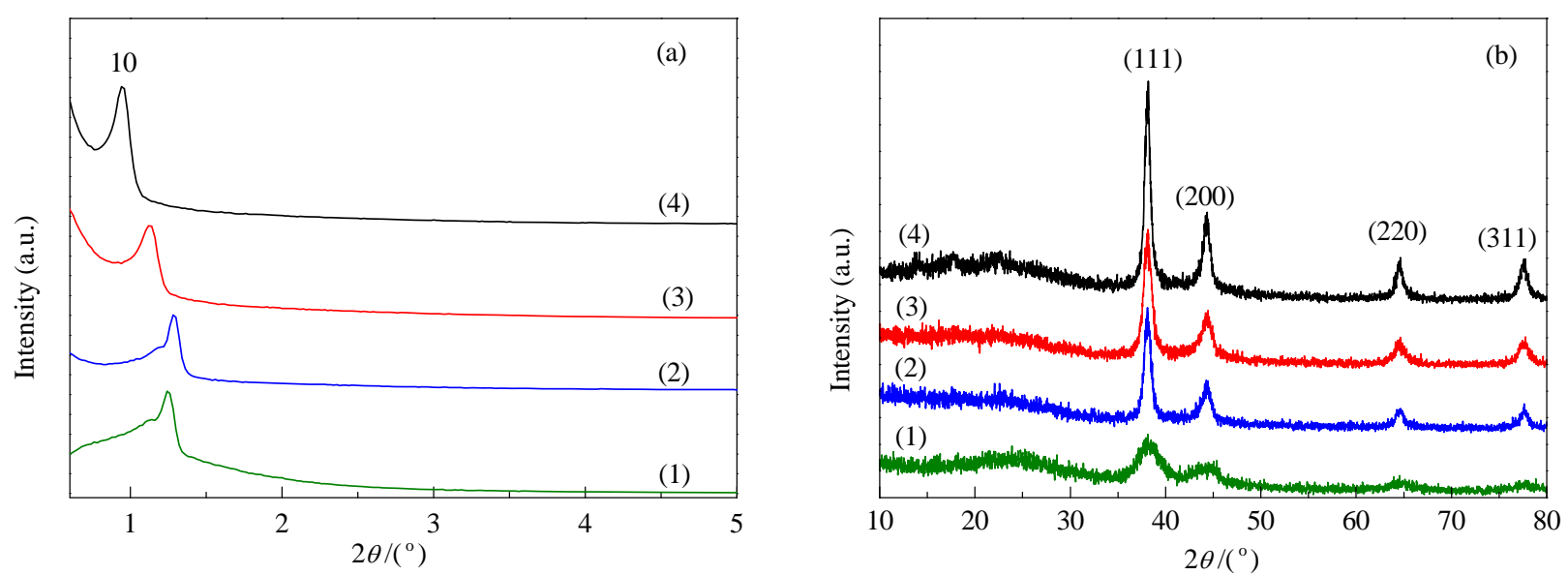

Fig. 3. Small-angle (a) and wide-angle (b) XRD patterns of Au encapsulated ordered mesoporous carbon as a function of Au nanoparticle size. (1) 3 nm; (2) $9 \mathrm{~nm}$; (3) $14 \mathrm{~nm}$; (4) $18 \mathrm{~nm}$. 
lattice constant.

The XPS analysis is a surface-sensitive technique with a sampling volume that extends from the surface of the sample to a depth of 1-5 nm [50]. The Au catalysts 3-, 9-, and 18-Au(6)/C display diffused peaks with binding energies in the region of 84 and $88 \mathrm{eV}$, which can be assigned to $\mathrm{Au} 4 f_{5 / 2}$ and $4 f_{7 / 2}$ in the metallic state (Fig. 5). However, these two peaks are extremely weak. Compared with the Au concentration estimated from the ICP-AES analysis, the surface and near-surface concentration of metallic $\mathrm{Au}$ is distinctly low. Similar phenomena have been found in mesoporous carbon-supported $\mathrm{Ni}$ or Fe catalysts, in which metal or oxide nanoparticles are immobilized inside the mesopore carbon walls [51,52]. Therefore, the present $\mathrm{Au}$-containing carbon materials also possess the intercalation of $\mathrm{Au}$ particles inside the pore walls, complementary to the electron microscopy analysis. Only $\mathrm{Au}, \mathrm{C}$, and $\mathrm{O}$ are detected, confirming the absence of any contamination from chlorine and sulfur for the catalyst.

The density of the thiol groups in the walls of the as-made materials was then fixed to $3.06 \mathrm{mmol} / \mathrm{g}$, and the Au content tuned in the synthesis batch. Finally, materials displaying 1.1-9.0 wt\% Au were loaded over carbon $(9-\mathrm{Au}(1) / \mathrm{C}$,
9-Au(6)/C, and 9-Au(9)/C).

These materials show similar XRD patterns and $\mathrm{N}_{2}$ sorption isotherms with the as-made counterpart material synthesized with the same thiol group density (Fig. 6), indicating the retention of the monodispersed $\mathrm{Au}$ nanoparticles, ordered mesostructure, high surface areas, large pore volumes and uniform pore sizes, including the catalyst with the highest Au content (9.0 wt\%). Interestingly, the TEM micrographs show that the Au nanoparticle size remains practically unchanged across this series of catalysts, only with a distinct increase in particle numbers (Fig. 7). This is in contrast to most heterogeneous catalysts, in which an increase in the loaded metal concentration would simultaneously lead to nanoparticle growth. Therefore, maintaining the same $\mathrm{Au}$ nanoparticle size across the loading level range after carbonization at $600{ }^{\circ} \mathrm{C}$ is possibly related to the thiol concentration in the as-made materials.

To further elucidate the effect of $\mathrm{Au}$ nanoparticle size as a function of thiol density in the as-made matrix, a sample of $18-\mathrm{Au}(1) / \mathrm{C}$ was synthesized with a reduced $\mathrm{Au}$ loading (1.3 wt $\%$ ) with the same thiol concentration of $1.55 \mathrm{mmol} / \mathrm{g}$. The TEM micrograph clearly shows the same particle size of $18 \mathrm{~nm}$ to that in 18-Au(6)/C. Furthermore, the ordered mesostructure
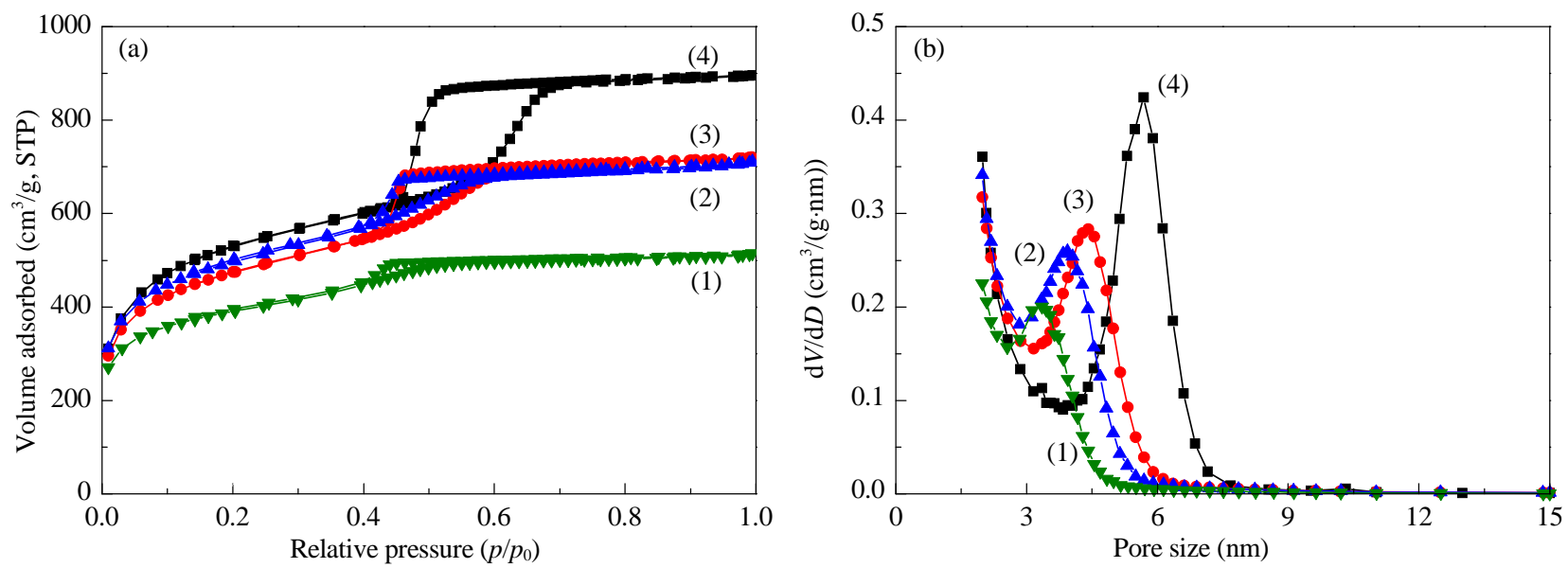

Fig. 4. $\mathrm{N}_{2}$ adsorption-desorption isotherms (a) and pore size distribution curves (b) for Au nanoparticle supported mesoporous carbon. (1) 3-Au(6)/C; (2) 9-Au(6)/C; (3) 14-Au(6)/C; (4) 18-Au(6)/C.
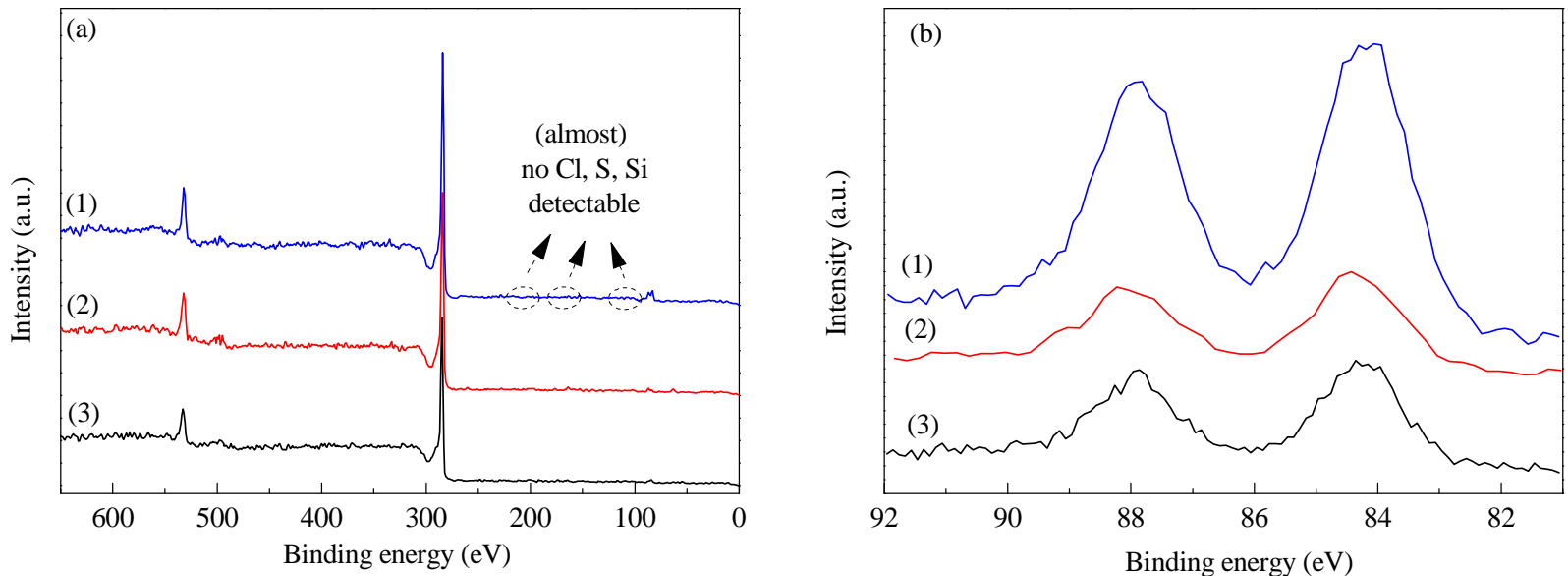

Fig. 5. XPS spectra of 3-Au(6)/C (a), 9-Au(6)/C (b), and 18-Au(6)/C (c). (b) is the localized enlargement of the spectra in (a) in relation to the Au 4f peaks. 

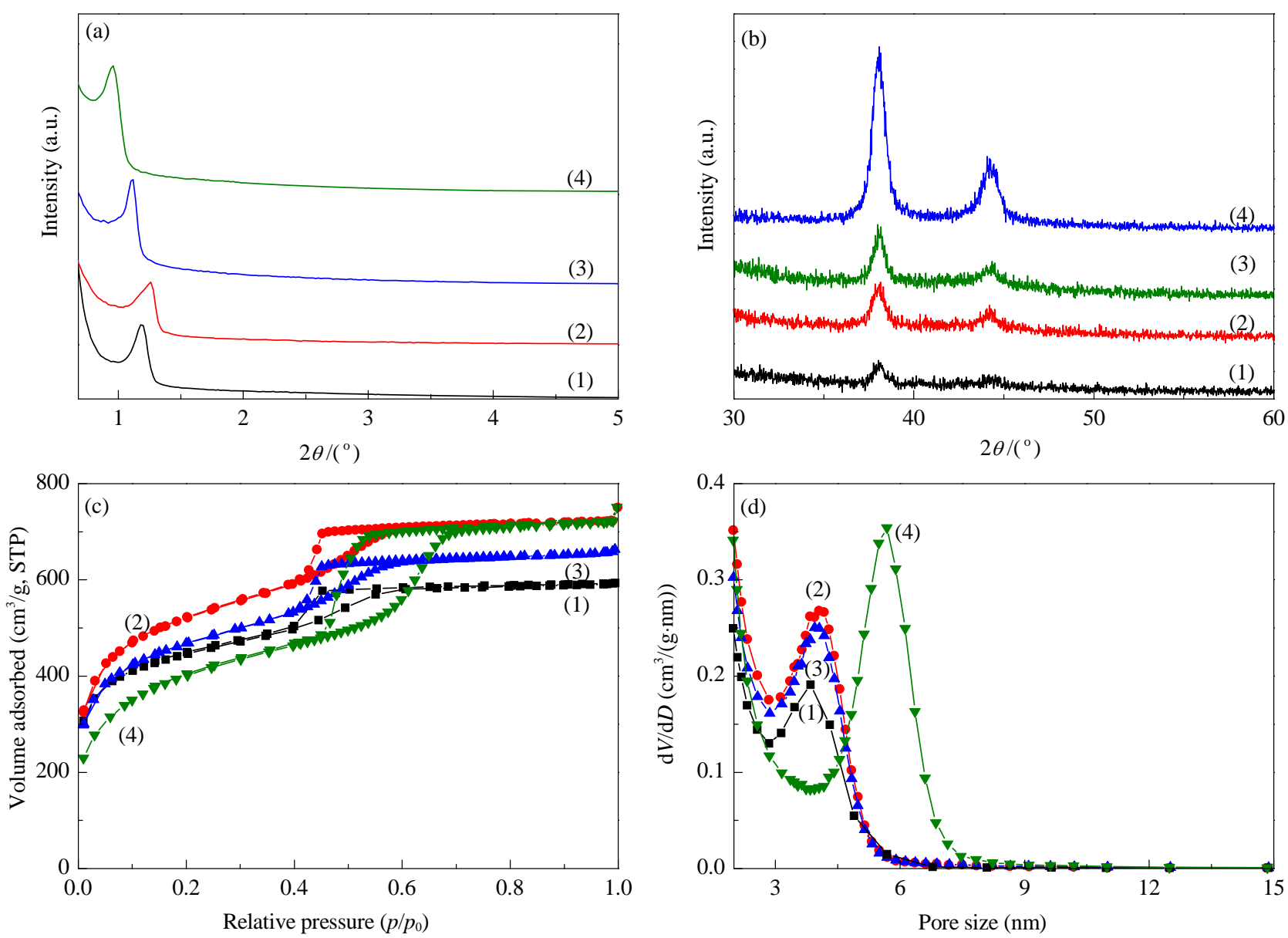

Fig. 6. Small-angle XRD (a), wide-angle XRD (b), $\mathrm{N}_{2}$ sorption isotherms (c), pore-size distribution curves (d) for $9 \mathrm{~nm}$ Au and $18 \mathrm{~nm}$ Au containing ordered mesoporous carbon as a function of varying Au loadings. (1) $1.1 \mathrm{wt} \%$ for $9 \mathrm{~nm} \mathrm{Au}$; (2) $1.8 \mathrm{wt} \%$ for $9 \mathrm{~nm} \mathrm{Au}$; (3) $9.0 \mathrm{wt} \%$ for $9 \mathrm{~nm} \mathrm{Au}$, (4) 1.3 wt $\%$ for $18 \mathrm{~nm} \mathrm{Au}$.

is retained (data not shown here). The well-resolved XRD diffractograms in both the small-angle and wide-angle ranges demonstrate the ordered mesophase and $f c c$ Au nanoparticles with an estimated size of approximately $18 \mathrm{~nm}$. The type-IV

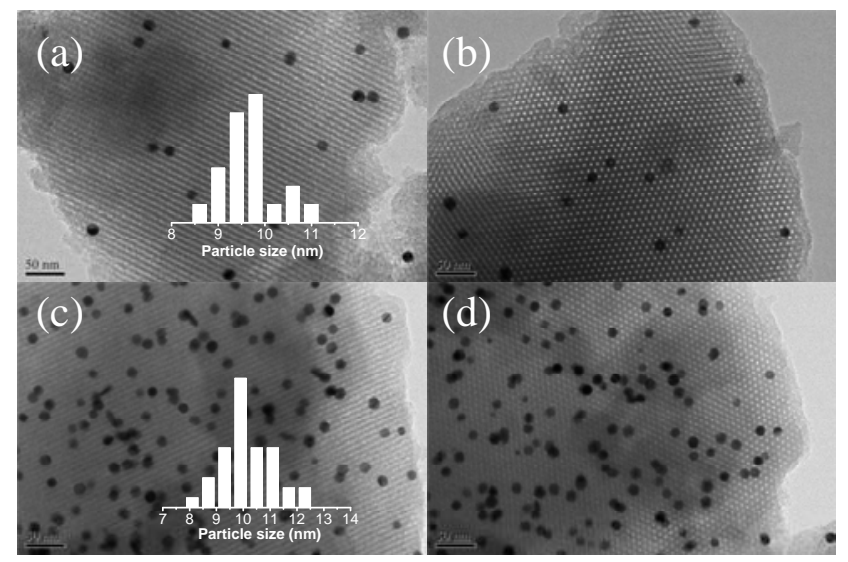

Fig. 7. TEM micrographs for $9-\mathrm{Au}(y) / \mathrm{C}$ with different $\mathrm{Au}$ loadings viewed along the (110) (a) and the (001) (b) directions. (a, b) $1.8 \mathrm{wt} \%$; (c, d) $9.0 \mathrm{wt} \%$. The inset shows the metal particle size distribution histogram. isotherms reveal the well-defined mesopores with a high surface area of $1349 \mathrm{~m}^{2} / \mathrm{g}$, a pore volume of $1.11 \mathrm{~cm}^{3} / \mathrm{g}$ and a bimodal pore-size distribution centered at $5.6 \mathrm{~nm}$ and below 2 nm (Fig. 6). These results are in agreement with those related to $18-\mathrm{Au}(6) / \mathrm{C}$.

\subsection{Discussion}

The pathway on the basis of a coordination-assisted triblock-copolymer self-assembly approach leading to the composites is shown schematically in Fig. 8.

The coupling agent of MPTMS containing reactive thiol groups was utilized as the inner wall component, which can react with preformed phenolic resins and co-condense with TEOS in the sol-gel resulting in the formation of a mesostructured framework with thiol functionality protruding from the walls [47]. The thiol functional group has an affinity to coordinate with a $\mathrm{Au}$ source, with a coordination number of two between the Au and S moieties, as analyzed by the Fourier transforms of EXAFS spectra [35]. The Au(III) species is reduced to $\mathrm{Au}(\mathrm{I})$ thiolate, similar to Au solutions stabilized by, for example, thiol-containing PTMP-PMAA ligands [53] and 


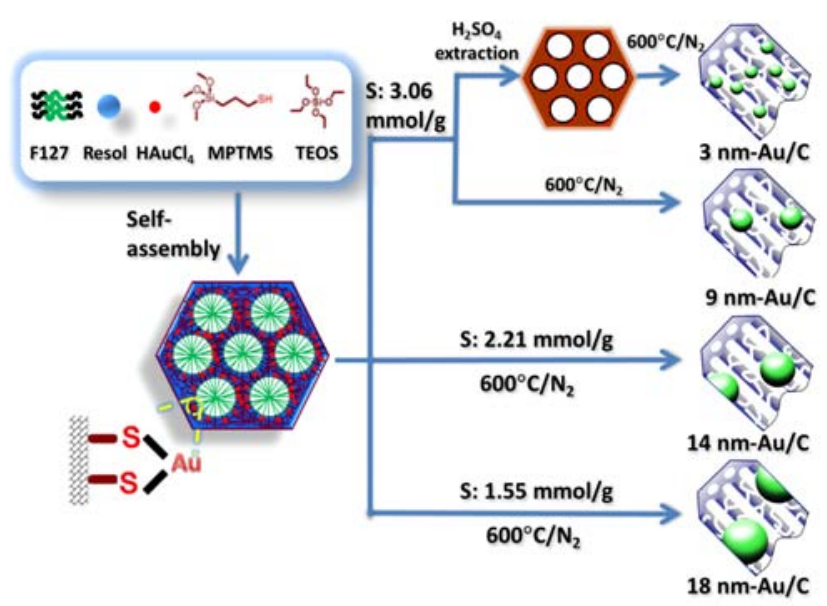

Fig. 8. General scheme for the size-control synthesis of ordered mesoporous $\mathrm{Au} / \mathrm{C}$ catalysts with $\mathrm{Au}$ nanoparticles intercalated to the carbon pore walls. From top to bottom: the thiol density ranges from 0.01 to $0.09 \mathrm{~g} / \mathrm{g}$, while the Au content remains constant. An additional sulfuric acid extraction step is performed for the $3-\mathrm{Au}(6) / \mathrm{C}$ material

$p$ - $\mathrm{HSCH}_{2}\left(\mathrm{C}_{6} \mathrm{H}_{4}\right) \mathrm{C}\left(\mathrm{CH}_{3}\right)_{3}$ [54]. The phenomenon is different with the $\mathrm{Au}(\mathrm{III})-\mathrm{Cl}$ coordination in both the reference $\mathrm{HAuCl}_{4}$ solution and the thiol-free synthetic solution. Therefore, the interaction among the $\mathrm{Au}$, silane, and resins are strengthened in the synthesis solution. Triblock copolymer assembly at the interface is induced by the hydrogen-bonding interaction between the hydrophilic EO segments and the hydroxyl groups of the resins and silicates followed by solvent evaporation to increase the polymer concentration above the critical micellar concentration (CMC).

In the preceding step, the assembling mesostructured inorganic-organic hybrid composite is thermopolymerized at 100 ${ }^{\circ} \mathrm{C}$ to form flaxen as-made films. The FT-IR spectrum for the as-made $9-\mathrm{Au}(6) / \mathrm{C}$ material exhibits several bands at 3400 , $3000-2800,1610,1460,1350,1100$, and $950 \mathrm{~cm}^{-1}$ corresponding to the characteristic stretching modes of phenolic resins, silicate and the triblock copolymer F127 (data not shown here), indicative of the organic-inorganic composite [41]. The C-S stretching mode at $690 \mathrm{~cm}^{-1}$ suggests the presence of a S-containing functional group [55]. However, the thiol group in IR is invisible under the current conditions $[55,56]$. The $S$ and Au signals are under the limit of detection in the XPS spectrum for the as-made 9-Au(6)/C sample, possibly because of the encapsulation of the thiol group and Au species in the framework and the triblock copolymer deep within the crystal.

Upon carbonization at $600{ }^{\circ} \mathrm{C}$ and the removal of silica, the carbon-based $\mathrm{Au}$ catalysts are obtained. The TGA curve for as-made $9-\mathrm{Au}(6) / \mathrm{C}$ material shows two predominant weight losses at $200-400$ and $400-900{ }^{\circ} \mathrm{C}$ (not shown here). The weight losses are related to the decomposition of the triblock copolymer and the organosiloxane and the polymerization of carbon, which results in a significant weight loss of small molecules, for example, $\mathrm{CH}_{4}$, and $\mathrm{CO}$. Sulfur content successively decreases from $3.06,0.98,0.45$ to $\sim 0 \mathrm{mmol} / \mathrm{g}$ as the pyrolysis temperature increases from room temperature to 250, 350, and $600{ }^{\circ} \mathrm{C}$ (determined by elemental analysis). This result demonstrates the simultaneous elimination of sulfur and pyrolysis of the polymeric framework with almost complete exclusion of sulfur residue in the final products.

Two key issues need to be addressed when tailoring the size of the metallic $\mathrm{Au}$ in the as-made material. The first factor to consider is the thiol density. In the absence of thiol functionality, phase separation of large $\mathrm{Au}$ nanoparticles $(\sim 150 \mathrm{~nm})$ and the ordered mesoporous carbon support take place $[35,41]$. The lack of S-Au coordination results in an agglomeration of $\mathrm{Au}$ nanoparticles which proceed to grow outside of the porous ordered mesostructure domains. Increasing the thiol group loading in the as-made matrix from 1.55 , to 2.21 and finally to $3.06 \mathrm{mmol} / \mathrm{g}$ results in the nanoparticle size continuously reducing from 18 to 14 and then to $9 \mathrm{~nm}$, regardless of the $\mathrm{Au}$ concentration.

The reduction of $\mathrm{Au}$ ions to metallic $\mathrm{Au}$ is inhibited by the strong coordination with the thiol group. At elevated temperatures, the thiol moieties are gradually removed. Au species, once in the absence of the thiol functionality-and hence having no coordination-are reduced and dramatically aggregate together because of the low-melting point. Simultaneously, the "soft" polymeric framework becomes "rigid". As a consequence, if the $\mathrm{S}$ species concentration is too low to stabilize the $\mathrm{Au}$ before the formation of the relatively "rigid" carbonaceous framework, the coagulation of $\mathrm{Au}$ nanoparticles inside mesopore channels is feasible with the possibility of penetration into the pore walls. At much higher S:Au ratios (ranging from 10.9 to 32.7), practical coordination in solution is necessary for the stabilization of the Au species in the solid during high temperature treatment. Stabilization hinders agglomeration until the "rigid" framework is fixed (at this stage, S-containing species should not be completely decomposed and the S-Au bond should remain), because the crystal growth energy in the solidified pore walls is high. As particle growth is confined by the framework, the particles remain homogenously dispersed in the matrix. For example, Au nanoparticles grow to $18 \mathrm{~nm}$ in 18-Au(6)/C-which incorporates a low thiol loading of 1.55 $\mathrm{mmol} / \mathrm{g}$ in the sol-gel-and therefore occupies two lattice cells. Increasing the thiol group loading protruding from the walls would strengthen the coordination and therefore, inhibit the reduction, mobility and aggregation of $\mathrm{Au}$ nanoparticles upon elevated temperatures. The sample 9-Au(6)/C which contains 3.06-mmol/g S in the as-made material can finally confine 9-nm nanoparticles in the matrix. The nanoparticles size is predominantly larger than the pore size but similar to the lattice constant for the mesophase. In these cases, the simultaneous formation of $\mathrm{Au}$ nanoparticles and relatively rigid silica-carbon framework favors the intercalation of monodispersed $\mathrm{Au}$ in the pore walls with no sign of any loss of integrity to the ordered mesopore arrays. Once the thiol concentration is fixed in the as-made material, the tuning of $\mathrm{Au}$ content shows negligible effect in the Au particle sizes within a defined range. For example, the samples $9-\mathrm{Au}(\mathrm{y}) / \mathrm{C}$, with the same $\mathrm{S}$ content as in the starting composite but having varying Au loadings between 1.8 and $9 \mathrm{wt} \%$, possess similar particle sizes. The 18-Au(1)/C with a low Au content of $1.3 \mathrm{wt} \%$ has a similar large particle of approximately $18 \mathrm{~nm}$ to $18-\mathrm{Au}(6) / \mathrm{C}$. It should be noted that in 
this present study, the $\mathrm{S}: \mathrm{Au}$ ratio in the as-made materials should be higher than 10 to achieve high loadings of monodispersed $\mathrm{Au}$.

The second factor to consider is the additional concentrated sulfuric acid treatment [41]. We attribute this step as pre-carbonization, which is normally adopted for nanocasting mesoporous carbon $[57,58]$. After sulfuric acid extraction, the IR spectrum for the as-made 3-Au(6)/C material shows a reduction in the vibration intensities at 1610, 1460 and 1350 $\mathrm{cm}^{-1}$ for phenolic resins, and in the $\mathrm{C}-\mathrm{H}$ vibrations between 3000 and $2800 \mathrm{~cm}^{-1}$ and the $\mathrm{C}-0$ vibrations at $1100 \mathrm{~cm}^{-1}$ for the triblock copolymer when compared with the initial composite $9-\mathrm{Au}(6) / \mathrm{C}$. This demonstrates further polymerization of the framework and partial removal of Pluronic F127 $[34,42,49]$. Concentrated sulfuric acid has also been reported as an alternative agent to remove triblock copolymers [42]. The C-S stretching mode at $690 \mathrm{~cm}^{-1}$ can be maintained, implying the protection of thiol functional groups. The comparison for $\mathrm{S}$ $2 p_{3 / 2}$ XPS spectra between $\mathrm{Au}$-free and as-made 3-Au(6)/C samples clearly demonstrate the formation of $\mathrm{Au}-\mathrm{S}$ interactions and the residual unreacted -SH in the latter. The accessibility of -SH to Au facilitates the coordination (Fig. 9) [41, 42]. Additionally, the XPS spectrum exhibiting a doublet with binding energies of 84.7 and $88.5 \mathrm{eV}$ were similar to those of $\mathrm{Au}(\mathrm{I})$ in an alkanethiolate complex for $\mathrm{Au} 4 f_{7 / 2}$ and $4 f_{5 / 2}$, confirming the stabilization of $\mathrm{Au}$ species by thiol groups [41]. The as-made $3-\mathrm{Au}(6) / \mathrm{C}$ sample displays a much smaller weight loss in the TGA curve than the 9-Au(6)/C material, in particular in the range below $400{ }^{\circ} \mathrm{C}$, because of the extraction of the block copolymer (data not shown here). On one hand, the partially condensed framework may favor the formation of a rigid framework at lower temperatures compared with the starting matrix, and thereafter, the fixing of Au nanoparticles after their reduction. Conversely, materials that liberate less heat during the decomposition of the organics also favor the stabilization of $\mathrm{Au}$ particles because heat is the main driving force for the mobility of nanoparticles. As a result, the immobilized Au nanoparticles are approximately $3 \mathrm{~nm}$ in size, much smaller than those in the direct carbonized sample with the same $\mathrm{Au}$ and thiol loadings $(\sim 9 \mathrm{~nm})$. Following this pre-carbonization idea,

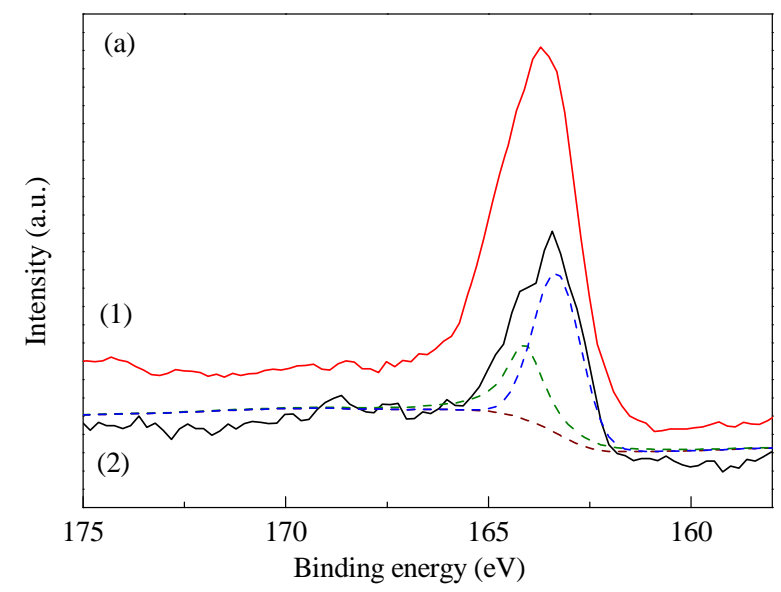

two additional samples were also synthesized. Beginning with the starting composite of $14-\mathrm{Au}(1) / \mathrm{C}$, the catalyst synthesized with the additional acid extraction step together with subsequent carbonization at elevated temperatures exhibited well-resolved diffraction peaks at low-angle two theta values in addition to an un-resolved peak at higher two theta angles, similar to the mesoporous carbon 3-Au(6)/C material. This result indicates that the catalyst possesses similar Au nanoparticle size of approximately $3 \mathrm{~nm}$ and retains a highly ordered mesostructure (Fig. 10). The BET surface area, pore volume and pore size of this catalyst is $1321 \mathrm{~m}^{2} / \mathrm{g}, 0.86 \mathrm{~cm}^{3} / \mathrm{g}$ and 3.8 $\mathrm{nm}$, respectively. The second sample is derived from 18-Au(6)/C via the two-step carbonization. Interestingly, this sample also exhibits analogous XRD patterns to 3-Au(6)/C in both small-angle and wide-angle ranges, indicating the restriction of the Au nanoparticle growth to $\sim 3 \mathrm{~nm}$ in the ordered carbon mesostructure (Fig. 10). These results show the importance of the pre-carbonized "rigid" framework by acid extraction to inhibit particle aggregation during the subsequent heating stage.

The final Au-containing mesoporous carbon materials have high surface areas, large pore volumes, interpenetrated, uniform bimodal mesopores. The pores are essential for diffusion and can therefore enhance the accessibility of the Au nanoparticles, which if the textural properties are not suitable, can minimize diffusion because of pore blockage by $\mathrm{Au}$ nanoparticles. Further investigation on the mass transfer effect is currently being studied.

Finally, the complete elimination of the coordination agent may show negligible effect on any catalytic performance for Au-containing mesoporous carbon catalysts. The coordination-assisted self-assembly approach adopted may establish a protocol that allows for the control of both the particle size and density of metal in porous carbon supports.

\section{Conclusions}

In summary, tailoring of the size and concentration of encapsulated Au nanoparticles supported on mesoporous carbon in the absence of protecting agents have been controlled by a

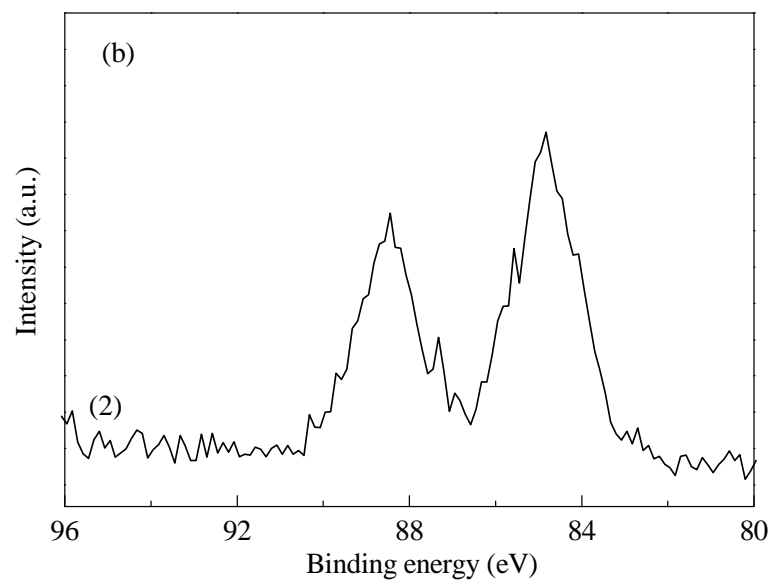

Fig. 9. XPS spectra for as-made $\mathrm{Au}-\mathrm{free}(\mathrm{a})$ and 3-Au(6)/C (b) composites in the $\mathrm{S} 2 p(\mathrm{~A})$ and $\mathrm{Au} 4 f$ region (b). 

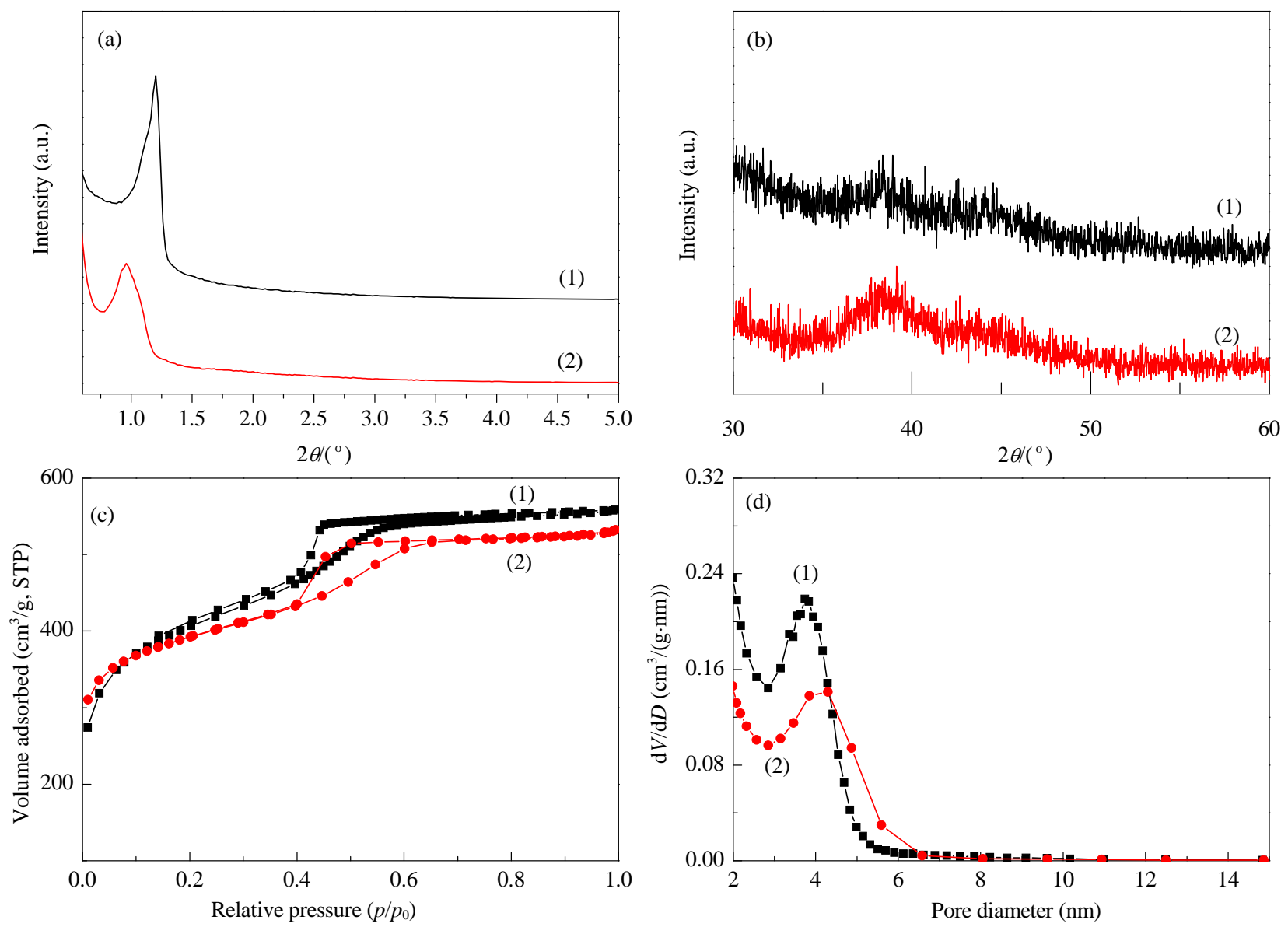

Fig. 10. Small-angle XRD (a), wide-angle XRD (b), $\mathrm{N}_{2}$ sorption isotherms (c), and pore-size distribution curves (d) for the 3-nm Au-containing mesoporous carbon derived from as-made 14-Au(1)/C (1) and as-made 18-Au(6)/C (2) via the two-step carbonization process.

coordination-assisted self-assembly approach. Au nanoparticles with controlled sizes between 3 and $18 \mathrm{~nm}$ and contents of 1.1-9.0 wt\% are thermally stable and do not sinter to large particles or migrate to the external surface of the carbon mesostructure upon high temperature treatment at $600{ }^{\circ} \mathrm{C}$. The increase of thiol group loading together with subjecting the as-made supports to an additional pre-carbonization step before pyrolysis reduces the $\mathrm{Au}$ nanoparticle size. The reduction of the particle size results in the modifications to the electronic properties of the Au nanoparticles. The supported nanogold catalysts exhibit high BET surface areas of $>1200 \mathrm{~m}^{2} / \mathrm{g}$, large pore volumes $>0.8 \mathrm{~cm}^{3} / \mathrm{g}$ and bimodal pore sizes with the larger mesopore in the range of 3.4-5.7 $\mathrm{nm}$ and smaller secondary pore at $2 \mathrm{~nm}$, showing potential applications in mass transfer, catalysis, adsorption and sensors.

\section{References}

[1] G. J. Hutchings, J. Catal., 1985, 96, 292.

[2] M. Haruta, T. Kobayashi, H. Sano, N. Yamada, Chem. Lett., 1987, 405.

[3] M. Haruta, Nature, 2005, 437, 1098.

[4] M. McEntee, W. Tang, M. Neurock, J. T. Yates Jr, J. Am. Chem. Soc., 2014, 136, 5116.
[5] W. Zhu, Y. J. Zhang, H. Zhang, H. Lv, Q. Li, R. Michalsky, A. A. Peterson, S. Sun, J. Am. Chem. Soc., 2014, 136, 16132.

[6] Z. Y. Zhang, Y. Wang, X. Li, W. L. Da, Chin. J. Catal., 2014, 35, 1846.

[7] S. Fountoulaki, V. Daikopoulou, P. L. Gkizis, I. Tamiolakis, G. S. Armatas, I. N. Lykakis, ACS Catal., 2014, 4, 3504.

[8] G. Li, D. E. Jiang, S. Kumar, Y. X. Chen, R. C. Jin, ACS Catal., 2014, 4, 2463.

[9] G. Li, R. C. Jin, J. Am. Chem. Soc., 2014, 136, 11347.

[10] H. Wei, X. Wei, X. Yang, G. Yin, A. Wang, X. Liu, Y. Huang, T. Zhang, Chin. J. Catal., 2015, 36, 160.

[11] V. I. Sobolev, K. Y. Koltunov, Appl. Catal. A, 2014, 476, 197.

[12] W. S. Lee, M. C. Akatay, E. A. Stach, F. H. Ribeiro, W. N. Delgass, J. Catal., 2014, 313, 104.

[13] G. Li, D. E. Jiang, C. Liu, C. Yu, R. Jin, J. Catal., 2013, 306, 177.

[14] S. Shabbir, Y. Lee, H. Rhee, J. Catal., 2015, 322, 104.

[15] X. Feng, X. Duan, G. Qian, X. Zhou, D. Chen, W. Yuan, J. Catal., 2014, $317,99$.

[16] S. Gil, N. Cuenca, A. Romero, J. L. Valverde, L. Sánchez-Silva, Appl. Catal. A, 2014, 472, 11.

[17] N. T. Khoa, S. W. Kim, D. H. Yoo, E. J. Kim, S. H. Hahn, Appl. Catal. A, 2014, 469, 159.

[18] G. R. Zhang, B. Q. Xu, Chin. J. Catal., 2013, 34, 942.

[19] A. Goguet, C. Hardacre, I. Harvey, K. Narasimharao, Y. Saih, J. Sa, J. Am. Chem. Soc., 2009, 131, 6973.

[20] H. Zhang, B. Dai, W. Li, X. Wang, J. Zhang, M. Zhu, J. Gu, J. Catal., 


\section{Graphical Abstract}

Chin. J. Catal., 2016, 37: 61-72 doi: 10.1016/S1872-2067(15)60917-2

Size-control growth of thermally stable Au nanoparticles encapsulated within ordered mesoporous carbon framework

Shuai Wang, Jie Wang, Xiaojuan Zhu, Jianqiang Wang, Osamu Terasaki, Ying Wan*

Shanghai Normal University, China; Shanghai Institute of Applied Physics, Chinese Academy of Sciences, China; Stockholm University, Sweden

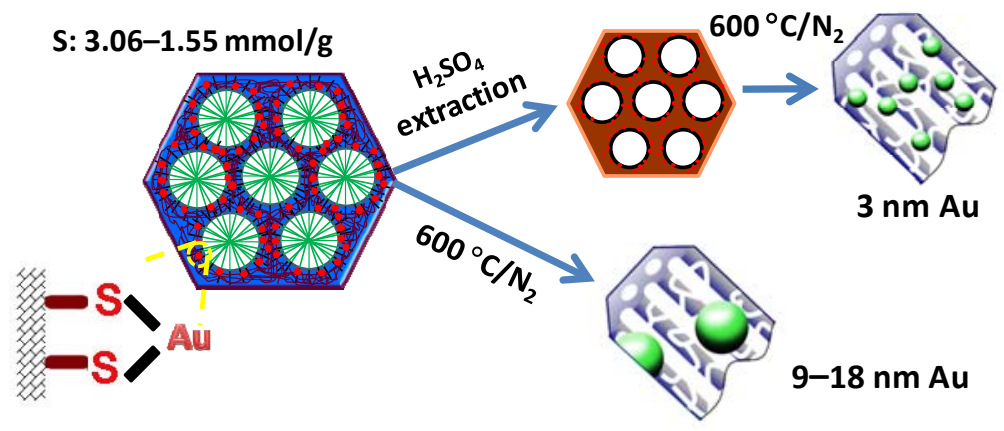

Thermally stable gold nanoparticles with sizes of 3-18 $\mathrm{nm}$ and free of protecting agent have been loaded onto ordered mesoporous carbon via a coordination-assisted self-assembly approach.

2014, 316, 141.

[21] L Prati, A Villa, A R Lupini, G M. Veith, Phys. Chem. Chem. Phys., 2012, 14, 2969.

[22] L. Prati, M. Rossi, J. Catal., 1998, 176, 552.

[23] T. Yoskamtorn, S. Yamazoe, R. Takahata, J. Nishigaki, A. Thivasasith, J. Limtrakul, T. Tsukuda, ACS Catal., 2014, 4, 3696.

[24] C. Fernandes, C. Pereira, A. Guedes, S. L. H. Rebelo, C. Freire, Appl. Catal. A, 2014, 486, 150.

[25] F. Porta, L. Prati, M Rossi, S Coluccia, G. Martra, Catal. Today, 2000, 61, 165.

[26] C. L. Bianchi, S. Biella, A. Gervasini, L. Prati, M. Rossi, Catal. Lett., 2003, 85, 91.

[27] M. L. Toebes, Y. H. Zhang, J. Hajek, T. A. Nijhuis, J. H. Bitter, A. J. van Dillen, D. Y. Murzin, D. C. Koningsberger, K. P. de Jong, J. Catal., 2004, 226, 215.

[28] R. Y. Zhong, K. Q. Sun, Y. C. Hong, B. Q. Xu, ACS Catal., 2014, 4, 3982.

[29] R. Y. Zhong, X. H. Yan, Z. K. Gao, R. J. Zhang, B. Q. Xu, Catal. Sci. Technol., 2013, 3, 3013.

[30] M. T. Bore, H. N. Pham, E. E. Switzer, T. L. Ward, A. Fukuoka, A. K. Datye, J. Phys. Chem. B, 2005, 109, 2873.

[31] K. K. R. Datta, B. V. S. Reddy, K. Ariga, A. Vinu, Angew. Chem. Int. Ed., 2010, 49, 5961.

[32] S. Jun, S. H. Joo, R. Ryoo, M. Kruk, M. Jaroniec, Z. Liu, T. Ohsuna, O. Terasaki, J. Am. Chem. Soc., 2000, 122: 10712.

[33] F. Kerdi, V. Caps, A. Tuel, Microporous Mesoporous Mater., 2011, 140: 89.

[34] Y. Meng, D. Gu, F. Q. Zhang, Y. F. Shi, H. F. Yang, Z. Li, C. Z. Yu, B. Tu, D. Y. Zhao, Angew. Chem. Int. Ed., 2005, 44, 7053.

[35] S. Wang, Q. Zhao, H. Wei, J. Q. Wang, M. Cho, H. S. Cho, O. Terasaki, Y. Wan, J. Am. Chem. Soc., 2013, 135, 11849.

[36] E. Besson, A. Mehdi, C. Reye, R. J. P. Corriu, J. Mater. Chem., 2009, $19,4746$.

[37] L. Chen, J. Hu, R. Richards, J. Am. Chem. Soc., 2009, 131, 914.

[38] B. Lee, H. Zhu, Z. Zhang, S. H. Overbury, S. Dai, Microporous Mesoporous Mater., 2004, 70, 71.
[39] P. Wu, P. Bai, Z. Lei, K. P. Loh, X. S. Zhao, Microporous Mesoporous Mater., 2011, 141, 222.

[40] H. Zhu, B. Lee, S. Dai, S. H. Overbury, Langmuir, 2003, 19, 3974.

[41] S. Wang, J. Wang, Q. Zhao, D. Li, J. Q. Wang, M. Cho, H. Cho, O. Terasaki, S. Chen, Y. Wan, ACS Catal., 2014, 4, 797.

[42] X. Zhuang, Q. Zhao, Y. Wan, J. Mater. Chem., 2010, 20, 4715.

[43] A. Balerna, S. Mobilio, Phys. Rev. B, 1986, 34, 2293.

[44] I. Coulthard, S. Degen, Y. J. Zhu, T. K. Sham, Can. J. Chem., 1998, 76, 1707.

[45] L. F. Mattheiss, R. E. Dietz, Phys. Rev. B, 1980, 22, 1663.

[46] J. T. Miller, A. J. Kropf, Y. Zha, J. R. Regalbuto, L. Delannoy, C. Louis, E. Bus, J. A. van Bokhoven, J. Catal., 2006, 240, 222.

[47] X. Zhuang, Y. Wan, C. Feng, Y. Shen, D. Zhao, Chem. Mater., 2009, $21,706$.

[48] Y. Wan, H. Wang, Q. Zhao, M. Klingstedt, O. Terasaki, D. Zhao, J. Am. Chem. Soc., 2009, 131, 4541

[49] R. Liu, Y. Shi, Y. Wan, Y. Meng, F. Zhang, D. Gu, Z. Chen, B. Tu, D. Zhao, J. Am. Chem. Soc., 2006, 128, 11652.

[50] S. Suzer, Appl. Spectrosc., 2000, 54, 1716.

[51] A. H. Lu, J. J. Nitz, M. Comotti, C. Weidenthaler, K. Schlichte, C. W. Lehmann, 0. Terasaki, F. Schüth, J. Am. Chem. Soc., 2010, 132, 14152.

[52] W. Wang, H. Y. Wang, W. Wei, Z. G. Xiao, Y. Wan, Chem. Eur. J., 2011, 17, 13461.

[53] A. B. Laursen, K. T. Hojholt, L. F. Lundegaard, S. B. Simonsen, S. Helveg, F. Schueth, M. Paul, J. D. Grunwaldt, S. Kegnoes, C. H. Christensen, K. Egeblad, Angew. Chem. Int. Ed., 2010, 49, 3504.

[54] P. M. Arnal, M. Comotti, F. Schueth, Angew. Chem. Int. Ed., 2006, 45, 8224.

[55] S. Ungureanu, M. Birot, G. Laurent, H. Deleuze, O. Babot, B. Julián-López, M. F. Achard, M. I. Popa, C. Sanchez, R. Backov, Chem. Mater., 2007, 19, 5786.

[56] K. Wilson, A. F. Lee, D. J. Macquarrie, J .H. Clark, Appl. Catal. A, 2002, 228, 127.

[57] M. Choi, R. Ryoo, Nat. Mater., 2003, 2, 473.

[58] R. Ryoo, S. H. Joo, S. Jun, J. Phys. Chem. B, 1999, 103, 7743. 


\title{
尺寸可控、高热稳定性有序介孔碳Au催化剂的合成
}

\author{
王 帅 ${ }^{\mathrm{a}}$ ，王 杰 ${ }^{\mathrm{a}}$, 朱小娟 ${ }^{\mathrm{a}}$, 王建强 ${ }^{\mathrm{b}}$, Osamu Terasaki ${ }^{\mathrm{c}}$, 万 颖, ${ }^{\mathrm{a}}{ }^{\mathrm{*}}$ \\ ${ }^{\mathrm{a}}$ 上海师范大学化学系, 资源化学教育部重点实验室, 上海市稀土功能材料重点实验室, 上海200234 \\ b 上海应用物理研究所, 上海市同步光源中心, 上海201204 \\ `斯德哥尔摩大学物理、无机和结构化学系, 阿伦尼乌斯实验室,斯德哥尔摩10691,瑞典
}

\begin{abstract}
摘要: 纳米 $\mathrm{Au}$ 催化剂被认为是具有商业价值的用于醇选择氧化的第二代催化剂. 这是因为 $\mathrm{Au}$ 氧化还原电势高, 化学稳定性 好, 可抑制易使Pt族元素中毒的胺等的毒化; 其次, 对于一些特定选择氧化和还原反应而言, 具有较优的反应选择性. 目前较 多的研究集中在调变 $\mathrm{Au}$ 纳米颗粒与氧化物载体的相互作用,获得协同效应. 例如,利用 $\mathrm{CeO}_{2}$ 纳米晶为载体,沉积 $\mathrm{Au}$ 纳米颗粒 (约3 $\mathrm{nm}$ ), 使 $\mathrm{CeO}_{2}$ 部分还原为非计量比的催化材料, 活化氧并获得高选择氧化性能. 碳是相对惰性的载体, 与 $\mathrm{Au}$ 相互作用力 弱, 因此可被用于研究Au纳米颗粒本征催化性能. 但负载碳金催化剂在焙烧甚至还原过程中易团聚, 且在反应中易流失, 可 能导致活性下降. 利用胶体沉积法可获得介孔碳担载纳米Au催化剂, 对葡萄糖选择氧化具有很高的催化活性和选择性. 但 是,制备中使用的保护剂残留经常被忽略. 由于立体效应或电子结构调变作用,保护剂可能影响 $\mathrm{Au}$ 催化剂活性或稳定性.

我们前期建立了反应单体参与的自组装技术合成功能化介孔碳路线, 一步在介孔碳骨架中掺杂氧化物纳米催化剂. 本 文从介孔催化材料的结构出发, 设计“镶嵌”在碳骨架中的纳米Au颗粒. 采用配位作用辅助表面活性剂自组装技术, 以苯酚 和甲醛为碳前体, 引入含統基硅烷偶联剂, 通过配位作用稳定金离子, 获得尺寸可控介孔碳限域纳米Au催化剂. 低温炭化中, 由于䘪基-金的配位作用阻抑金属移动或团聚,高温下聚合物炭化为相对刚性的碳骨架. 此时, Au纳米颗粒被相邻介孔孔墙 限制. 硅烷偶联剂可除去, 不影响碳载体, 并可产生丰富二级孔道, 获得多级孔道介孔碳材料.

$X$ 射线衍射和透射电镜结果显示, 所合成的催化剂中Au颗粒的尺寸可控, 为3-18nm, 且具有单分散性,均匀地分散在整 个介孔碳骨架中, 其含量为1.1-9.0 wt\%. 金碳催化剂具有有序的二维六方介孔结构. 能量散射谱(EDX)也证明了催化剂只含 有 $\mathrm{C}, \mathrm{O}$ 和 $\mathrm{Au}$ 元素, 没有 $\mathrm{S}$ 和 $\mathrm{Si}$ 元素的残留. X射线光电子能谱(XPS)结果显示催化剂表面的 $\mathrm{Au}$ 含量远远低于ICP的测试结果, 也证明了 $\mathrm{Au}$ 纳米颗粒分布在介孔碳骨架内, 同时只含有 C, O和Au元素也与EDX相符. X射线近边吸收谱结果表明, 随着颗 粒尺寸的减小, $\mathrm{Au}$ 表面电子性质发生改变. $\mathrm{N}_{2}$ 吸脱附等温线显示, 有序介孔碳金催化剂具有典型的第IV型曲线, 说明孔径分 布范围较窄, 主孔道尺寸为3.4-5.7 nm. 值得注意的是, 低压力段吸附量显示明显突跃, 暗示其具有一套约为 $2 \mathrm{~nm}$ 的次级介 孔. 所有的催化剂都具有高的比表面积 $\left(1269-1743 \mathrm{~m}^{2} / \mathrm{g}\right)$ 和大的孔体积 $\left(0.79-1.38 \mathrm{~cm}^{3} / \mathrm{g}\right)$. Au纳米颗粒具有高的热稳定性, 在 惰性气氛中, 即使在 $600^{\circ} \mathrm{C}$ 也未见明显聚集长大.

进一步讨论了合成中影响金纳米颗粒尺寸的重要影响因素. (1)颈基含量: 通过调节統基组分的含量, 可以调控催化剂 中 Au纳米颗粒的尺寸 $(9-18 \mathrm{~nm})$. 需要强调的是, Au纳米颗粒尺寸与巯基在新合成材料中的浓度有关, 当颈基含量在所研究 的范围中时(1.55-3.06 mmol/g), Au纳米颗粒尺寸仅仅与巯基浓度有关, 而与Au浓度无关. (2)硫酸预炭化处理: 新合成的材 料经过一步硫酸预炭化处理, 可以得到尺寸为 $3 \mathrm{~nm}$ 的有序介孔碳金催化剂. 表征结果证明, 经过硫酸预碳化处理, 大量表面 活性剂被除去, 同时聚合物载体发生部分碳化, 有助于在后续高温炭化中保护 $3 \mathrm{~nm}$ 金颗粒不团聚. 尺寸可控、高热稳定性、 无配体保护的有序介孔碳负载Au催化剂有望应用在催化和传感器等领域.
\end{abstract}

关键词: 金纳米颗粒; 尺寸; 碳; 介孔

收稿日期: 2015-03-03. 接受日期: 2015-05-08. 出版日期: 2016-01-05.

*通讯联系人. 电话: (021)64322516; 传真: (021)64322511; 电子信箱: ywan@shnu.edu.cn

基金来源：国家重点基础研究发展计划(973计划, 2013CB934102); 国家自然科学基金(21322308, 21173149); 教育部创新团队发 展计划(PCSIRT-IRT1269); 教育部高等学校博士学科点基金(20123127110004); 上海市科委和教委基金(11JC1409200，DZL123， S30406).

本文的英文电子版由Elsevier出版社在ScienceDirect上出版(http://www.sciencedirect.com/science/journal/18722067). 